\title{
TERRESTRIAL LASER SCANNER FOR METRIC EXTRACTION IN EUCALYPTUS UNDER DIFFERENT IMPLANTATION SYSTEMS
}

\author{
Marieli Sabrina Ruza ${ }^{*}$, Ana Paula Dalla Corte ${ }^{2}$, Alessandro Camargo Angelo ${ }^{3}$, \\ Carlos Roberto Sanquetta ${ }^{4}$, Vagner Alex Pesck ${ }^{5}$ \\ 1*Universidade Federal do Paraná, Programa de Pós-graduação em Engenharia Florestal - Curitiba, Paraná, Brasil - \\ marielisabrinaruza@yahoo.com.br \\ ${ }^{2}$ Universidade Federal do Paraná, Departamento de Ciências Florestais, Curitiba, Paraná, Brasil - anapaulacorte@gmail.com \\ ${ }^{3}$ Universidade Federal do Paraná, Departamento de Ciências Florestais, Curitiba, Paraná, Brasil - alessandrocangelo@ gmail.com \\ ${ }^{4}$ Universidade Federal do Paraná, Departamento de Ciências Florestais, Curitiba, Paraná, Brasil - carlossanquetta@ gmail.com \\ ${ }^{5}$ Universidade Estadual do Centro Oeste, Departamento de Engenharia Florestal vapesck@ unicentro.br
}

Received for publication: 11/12/2019 - Accepted for publication: 03/05/2020

\begin{abstract}
Resumo
Laser scanner terrestre para extração de métricas em Eucalyptus sob diferentes sistemas de implantação. $\mathrm{O}$ objetivo deste trabalho foi avaliar a influência do sistema de implantação na extração das métricas de Eucalyptus benthamii obtidas com laser scanner terrestre (TLS) e inventário tradicional, testando a hipótese de que os métodos de extração não apresentam diferenças significativas. A área de estudo é composta por um sistema convencional de plantio sob espaçamento de $3 \times 2 \mathrm{~m}$ e por um sistema iLF (integração lavoura-floresta), sob espaçamento de $14 \times 2 \mathrm{~m}$. Foi realizado um inventário tradicional, para obtenção das variáveis dap (diâmetro à 1,3 m de altura) e altura total (h), juntamente com a coleta de dados com o TLS. No processamento da nuvem de pontos foi realizada a extração manual das métricas dap e h por varredura simples. $\mathrm{O}$ volume total (v) foi estimado por uma equação ajustada que condiz com as características da área de estudo. Para a estimativa da variável biomassa acima do solo (AGB) foram ajustados modelos com base em dados de AGB disponibilizados pelo projeto NITA e pelo BIOFIX. No sistema iLF a melhor visualização das árvores, facilitou a extração das métricas obtendo menor variação entre os dados. Os valores de dap, v e AGB no sistema iLF foram maiores quando comparados ao sistema convencional, porém ao incluir o número de árvores por hectare, o sistema convencional é mais produtivo. A hipótese levantada inicialmente no trabalho foi confirmada. Portanto, os métodos de extração de métricas do inventário tradicional e do TLS não apresentaram diferenças significativas para os dois sistemas de implantação considerados.

Palavras-chave: inventário florestal; nuvem de pontos; varredura simples.
\end{abstract}

\begin{abstract}
This study evaluates the influence of the cropping system in the extraction of Eucalyptus benthamii metrics by terrestrial laser scanner (TLS) and by traditional inventory. The hypothesis is that the extraction methods do not differ significantly from each other. The study area consists of a conventional planting system under $3 \times 2$ $\mathrm{m}$ spacing, and a CFI (crop-forest integration) system under 14 × $2 \mathrm{~m}$ spacing. To obtain the variables DBH (diameter at $1.3 \mathrm{~m}$ aboveground) and total height $(\mathrm{H})$, we used a traditional inventory and collected data with TLS. For point cloud processing, we manually extracted the metrics DBH and $\mathrm{H}$ by simple scanning. We estimated total volume $(\mathrm{V})$ by a fitted equation that matches the characteristics of the study area. To estimate above-ground biomass (AGB), we fitted models based on AGB data provided by the NITA project and by BIOFIX. Better visualization of trees in the CFI system facilitated metric extraction, leading to less data variability. In addition, $\mathrm{DBH}, \mathrm{V}$, and AGB values were higher in the CFI system compared to the conventional system. However, when including the number of trees per hectare, the conventional system is more productive. The initial hypothesis was confirmed. Therefore, metric extraction using the traditional inventory and TLS methods did not differ significantly for the two cropping systems considered.

Keywords: forest inventory; point cloud; simple scanning.
\end{abstract}

\section{INTRODUCTION}

Advances in forestry technology have focused on the search for new ways to estimate dendrometric variables. Laser scanning provides three-dimensional forest information, and has shown to be promising in forestry. The technological advances of the last decade in Terrestrial Laser Scanner (TLS) have allowed the development of accurate and increasingly cheaper sensors (PASCU et al., 2020).

Terrestrial Laser Scanner (TLS) enables fast, accurate, and automatic recording of the forest structure (LIANG et al., 2018; FARDUSI et al., 2017; MOSKAL, ZHENG, 2012). This procedure includes the pulsing of thousands of laser beams in the environment, and the recording of their returns in three-dimensional coordinates, generating a 3D point cloud (NEWNHAN et al., 2015). This enables extraction of dendrometric variables from tree reconstitution, becoming an alternative to traditional measurement methods in forest inventories (KANKARE et al., 2015). Moreover, TLS enables simple scanning, with a single scanning point (ASTRUP et al., 2014); or 
multiple scanning, in which the equipment scans several forest points (DASSOT et al., 2011). Simple scanning may lead to the problem of tree occlusion, which is overcome by multiple scanning. The latter, however, demands more time for data acquisition and preprocessing efforts (SHAO et al., 2020).

Different silvicultural systems result in different growth of dendrometric variables. In this sense, CFI (crop-forest integration) systems are expanding in Brazil. These systems are innovative and can help in the recovery of degraded areas (ASSIS et al., 2015). According to the Nationally Determined Contribution (NDC) under the Paris Agreement (BRAZIL, 2015), Brazil has committed to deploy 5 million hectares under the CFI system by 2030. Another commitment is to restore, additionally, 15 million hectares of degraded pastures by 2030 (REIS et al., 2017). There are several alternatives to make these areas productive again, such as implementing CFI systems that include livestock.

Considering the increase and the incentives for the implantation of integrated systems in the Brazilian territory, it will be necessary to adapt or develop methods and processes to obtain dendrometric variables suitable for the conditions of these systems. Therefore, this study evaluates the influence of different cropping systems (conventional and crop-forest integration - CFI) in the extraction of Eucalyptus benthamii metrics by terrestrial laser scanner (TLS) and by traditional forest inventory. The hypothesis is that the extraction methods do not differ significantly from each other.

\section{MATERIALS AND METHODS}

\section{Study Area}

The study area belongs to the experimental farm Canguiri of the Federal University of Paraná (UFPR), and is part of the NITA (Center for Technological Innovation in Agriculture) project. This project develops knowledge from the implementation of SIPA (Integrated Agricultural Production Systems) projects, applying different agricultural and zootechnical practices to production systems.

The experimental farm Canguiri is located in Pinhais city, metropolitan region of Curitiba, between the following geographical coordinates: $25^{\circ} 22^{\prime} 38^{\prime \prime}$ and $25^{\circ} 24^{\prime} 46^{\prime \prime}$ South latitude, 49 $09^{\prime} 05^{\prime \prime}$ and 49 06 ' 40" West longitude. It has an area of 440 ha, and average altitude of $920 \mathrm{~m}$ (Oliveira Junior et al., 2010).

Conventional planting system is a very common model in Brazil, being adopted by big reforestation companies in the forestry sector. It comprises a high density of trees per hectare, and initial spacing is usually $3 \mathrm{x}$ $2 \mathrm{~m}$. The conventional planting system of the study area corresponded to 0.48 hectares, in which we evaluated 61 trees. The CFI (crop- forest integration) system, in turn, corresponded to 1.41 hectares, in which we considered an initial spacing of $14 \times 2 \mathrm{~m}$. In this condition, we evaluated 69 trees distributed among 10 planting rows. Both systems consisted of approximately four-year-old Eucalyptus benthamii Maiden et Cambage trees. We considered the same soil preparation, planting method, and weed control for both systems.

\section{Measurement of the dendrometric variables DBH and total height}

In both systems, we measured the diameter of trees at $1.3 \mathrm{~m}$ height with a tape measure, and later

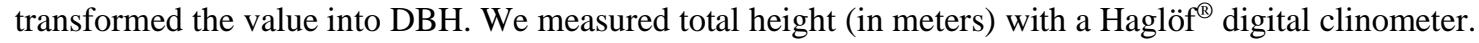

For data acquisition with TLS, we used a Leica ScanStation P40 at a scanning resolution of $6.3 \mathrm{~mm}$, generating approximately 40 million points in each collected position (10,054 Hz x 4,050 V). We performed a total of five $360^{\circ}$ scans (horizontal axis) (Figure 1) and captured two hundred and sixty-six 4 Mpixel images, forming a mosaic of 700 Mpixels, with a resolution of 1,920x1,920, which helped in the extraction of tree metrics.

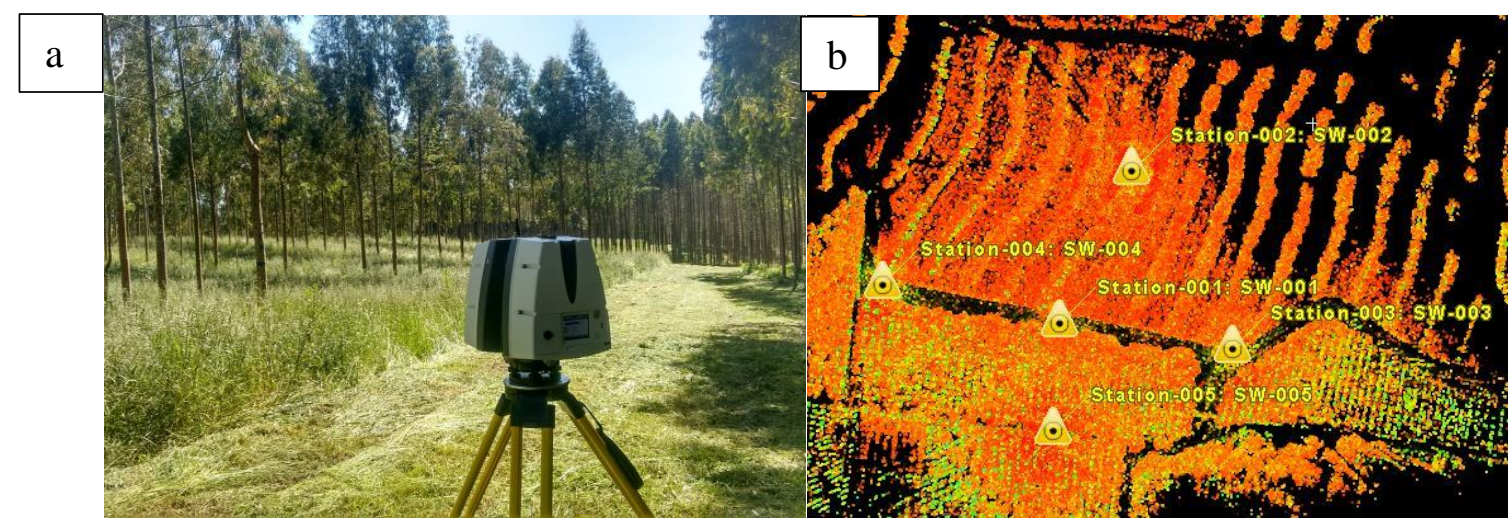

Figure 1. Leica ScanStation p40 laser scanner (a) and its position in the field for data collection (b).

Figura 1. Laser Scanner Leica Scanstation p40 (a) e seu posicionamento em campo para a coleta de dados (b).

FLORESTA, Curitiba, PR, v. 51, n. 2, p. 512-520, abril/jun 2021.

Ruza, M. S. et.al.

ISSN eletrônico 1982-4688

DOI: $10.5380 /$ rf.v51 i2. 70699 
In point cloud processing, we extracted the metrics DBH and total height $(\mathrm{H})$ by simple scanning, with vector information extraction on a scanning plane perpendicular to the $\mathrm{Z}$ axis. We extracted the metrics manually, according to the following steps: 1) individualization of the object of interest; 2) elevation of the scanning plane to a height of $1.30 \mathrm{~m}$ and creation of the circumference with subsequent extraction of the metric DBH (Figures 2a and $2 b)$; 3) measurement of the distance between the highest and lowest points of each tree to obtain total height (Figure 2c). For extracting the diameters, we used the simple circle fitting method (BU and WANG, 2016). For processing, we used the software Leica Cyclone version 9.2.1.

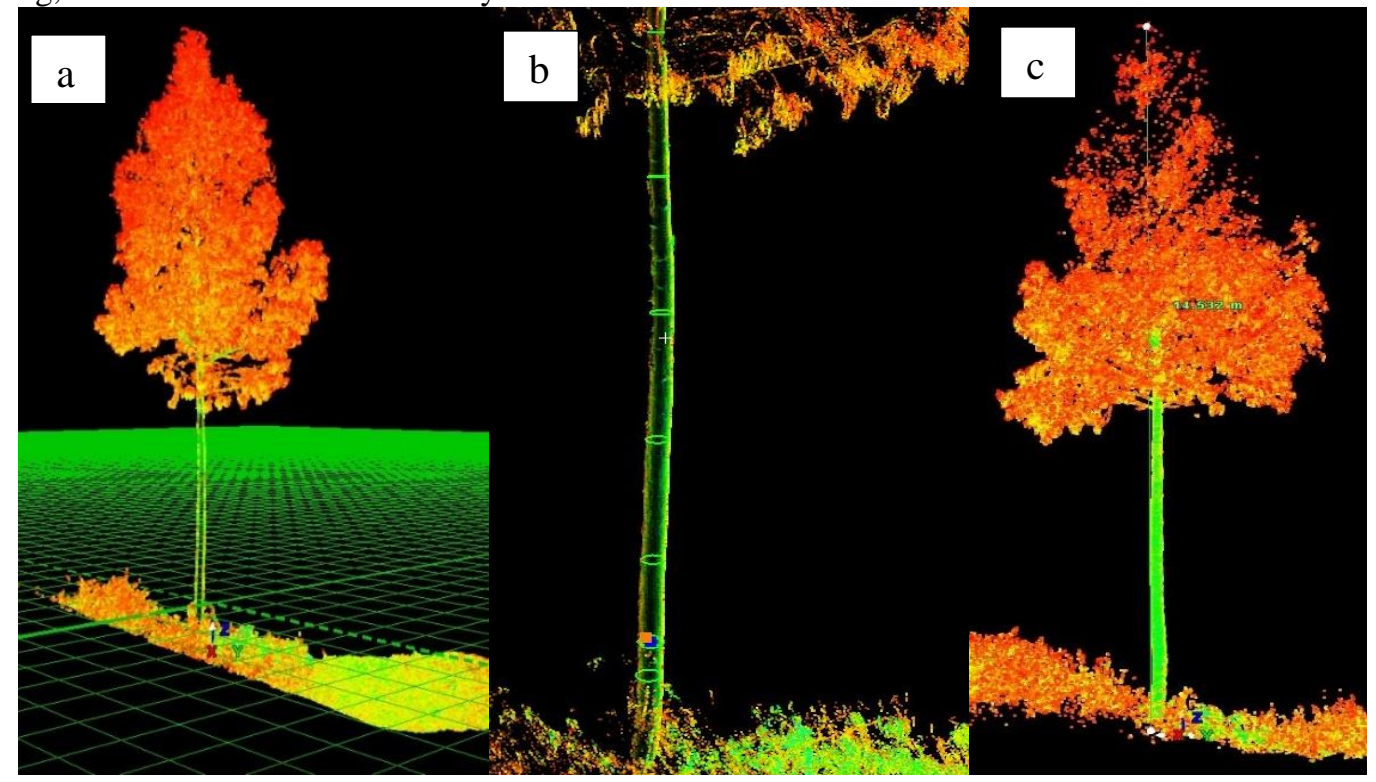

Figure 2. Processing steps for extracting the metrics DBH and $\mathrm{H}$ obtained by TLS for Eucalyptus benthamii.

Figura 2. Demonstração das etapas do processamento para extração das métricas de dap e H obtidos por TLS para Eucalyptus benthamii.

\section{Calculation of volume and AGB (above-ground biomass)}

We calculated the individual volume from the Schumacher-Hall equation adjusted by Figueiredo et al. (2014) (Equation 1). These authors used this equation for a Eucalyptus dunnii Maiden stand located in Telêmaco Borba city, Paraná State, Brazil, and obtained an adjusted coefficient of determination (adj. $\mathrm{R}^{2}$ ) of 0.989 and standard error of the relative estimate (Syx\%) of $8.26 \%$. We used this equation to calculate the individual volume from the metrics DBH and $\mathrm{H}$, obtained by traditional inventory and by TLS.

$$
\ln v=0,000018+1,77298 * \ln D B H+1,37336 * \ln H
$$

where: $\ln =$ Neperian logarithm; $\mathrm{v}=$ volume $\left(\mathrm{m}^{3}\right) ; \mathrm{DBH}=$ diameter at $1.30 \mathrm{~m}$ aboveground $(\mathrm{cm}) ; \mathrm{H}=$ total height $(\mathrm{m})$.

To estimate individual dry above-ground biomass (AGB), we fitted an equation using 22 trees quantified by the NITA project. This project quantified above-ground biomass in 11 five-year-old trees in the conventional system and 11 trees with the same age in the CFI system. Moreover, we used data from 24 trees quantified by the BIOFIX (Center for Excellence in Biomass Carbon Fixation Studies) team, corresponding to the species: Eucalyptus grandis W. Hill ex Maiden (six individuals), Eucalyptus saligna Smith (seven individuals), and Eucalyptus dunnii (eleven individuals), with ages varying between 8 and 20 years.

With data from these 46 trees, we fitted five models to estimate the independent variable individual aboveground biomass using DBH, total height, and their combinations as dependent variables. Table 1 shows the tested models.

Table 1. Models used to estimate above-ground biomass in Eucalyptus.

Tabela 1. Modelos utilizados para estimativa de biomassa acima do solo de Eucalyptus.

\begin{tabular}{rcc}
\hline Model & Model in its linear form & Author \\
\hline 1 & $\mathrm{AGB}=\beta 0+\beta 1 *\left(\mathrm{DBH}^{2} * \mathrm{H}\right)$ & Spurr \\
2 & $\ln \mathrm{AGB}=\beta 0+\beta 1 * \ln (\mathrm{DBH} * \mathrm{H})$ & - \\
3 & $\ln \mathrm{AGB}=\beta 0+\beta 1 * \ln \mathrm{DBH}^{2}$ & - \\
4 & $\mathrm{AGB}=\beta 0+\beta 1 * \mathrm{H}+\beta 2 * \mathrm{DBH}^{2}+\beta 3 *\left(\mathrm{DBH}^{2} * \mathrm{H}\right)$ & Stoate \\
5 & $\mathrm{AGB}=\beta 0+\beta 1 * \mathrm{DBH}+\beta 2 * \mathrm{DBH}^{2}+\beta 3 * \mathrm{DBH}^{*} \mathrm{H}+\beta 4 *\left(\mathrm{DBH}^{2} * \mathrm{H}\right)+\beta 5 * \mathrm{H}$ & Meyer \\
\hline
\end{tabular}

$\beta 0, \beta 1, \beta 2, \beta 3, \beta 4=$ model coefficients; ln = Neperian logarithm; $\mathrm{AGB}=$ individual above-ground biomass $(\mathrm{kg}) ; \mathrm{DBH}=$ diameter at 1.30 aboveground $(\mathrm{cm}) ; \mathrm{H}=$ total height $(\mathrm{m})$.

FLORESTA, Curitiba, PR, v. 51, n. 2, p. 512-520, abril/jun 2021.

Ruza, M. S. et.al.

ISSN eletrônico 1982-4688

DOI: 10.5380/rf.v51 i2. 70699 
We assessed the quality of the fitted models using the following statistical criteria: adjusted coefficient of determination $\left(\operatorname{adj} . \mathrm{R}^{2}\right.$ ); standard error of the absolute (Syx) and relative (Syx\%) estimate; F value and graphical analysis of the residues (in percentage) as a function of the variable of interest (biomass). After analyzing statistical criteria and the graphs of residues, we chose the model with the best results to estimate AGB for individuals who had the metrics obtained by traditional inventory and extracted by TLS, for the conventional planting system and for the CFI system.

\section{Statistical analysis of the metrics DBH, H, V, and AGB}

After extracting the metrics from the TLS cloud and generating the volume and AGB estimates, we compared the dataset with the measurements from the traditional inventory through multivariate analysis in MATLAB R2018b. We analyzed whether there was statistical difference between the values of the variables: $\mathrm{DBH}$, total height, volume, and AGB, obtained by traditional forest inventory (field) in comparison to the metrics extracted by TLS, for the conventional system and for the CFI system. For that, we made an inference about the paired mean vectors using the Hotelling's $\mathrm{T}^{2}$-Test (Equation 2). This test is analogous to the t-Student test used in univariate analysis.

$$
T^{2}=n(\underline{\bar{D}}-\underline{\delta})^{\prime} S_{d}^{-1}(\underline{\bar{D}}-\underline{\delta})
$$

where: $T^{2}=$ Hotelling's $T^{2}, n=$ number of samples,

$$
\begin{gathered}
\bar{D}=\frac{1}{n} \sum_{j=1}^{n} \underline{D}_{j} \\
d_{1 j}=X_{11 j}-X_{21 j} \\
d_{2 j}=X_{12 j}-X_{22 j} \\
\vdots \\
d_{p j}=X_{1 p j}-X_{2 p j} \\
D_{j}^{\prime}=\left[\begin{array}{lll}
\underline{d}_{1} & \underline{d}_{2} \quad \cdots \quad \underline{d}_{p}
\end{array}\right] \\
S_{d}=\frac{1}{n-1} \sum_{j=1}^{n}\left(\underline{D}_{j}-\underline{\bar{D}}\right)\left(\underline{D}_{j}-\underline{\bar{D}}\right)^{\prime}
\end{gathered}
$$

We compared the results using $F_{p, n-p}(\alpha)$, also called F-distribution, at $99 \%$ probability (Equation 3 ).

$$
T^{2} \geq \frac{(n-1) p}{n-p} F_{p, n-p}(\alpha)
$$

where: $n=$ number of samples, $p=$ parameters, $F=$ tabulated value of $F$

\section{RESULTS}

\section{Analysis of dendrometric variables}

The DBH metrics showed a linear relationship in the conventional system, with a correlation of 0.99 between the two collecting methods (Figure 3). The highest DBH values were close to $20 \mathrm{~cm}$. For the CFI system, the relationship was also linear, but the correlation was slightly lower (0.96). In this system, the highest DBH values were close to $25 \mathrm{~cm}$, and the results for this variable varied a lot. This fact can be explained by the greater spacing provided by this type of system, in addition to the influence of planting density on the observed variable. Among the variables evaluated, DBH showed the least variation in relation to the traditional forest inventory and the metrics obtained with TLS.

For height metrics in the conventional system, data dispersion was the highest among all variables, with a correlation of only 0.53 between the height obtained by traditional forest inventory and by TLS. There is difficulty in measuring the height of a tree in a forest stand. Thus, the result above can be justified by the following: difficulty in visualizing the base and the apex of the individuals in this system with the clinometer; difficulty in finding the lowest point of each tree (zero height) when extracting the data obtained with TLS; influence of the slope present in the study area.

Regarding volume in the conventional system, the correlation between the values obtained by traditional inventory and by TLS was 0.88 . Estimation of this variable considered DBH and H values; thus, its behavior was similar to that of the variable DBH regarding the relationship between metrics. Volume metrics showed a slightly higher correlation in the CFI system compared to the conventional system. This is because the variable height had also showed a higher correlation and less dispersion for this system, and was used for volume estimation. The same occurred for AGB metrics, which showed a higher correlation in the CFI system and greater dispersion in the conventional system.

In summary, the CFI system showed higher values for DBH metrics, resulting in higher estimates for volume and AGB metrics when compared to the conventional system, while height metrics differed little between the systems. These results highlight the influence of spacing on DBH values and the little influence of initial planting density on height. 


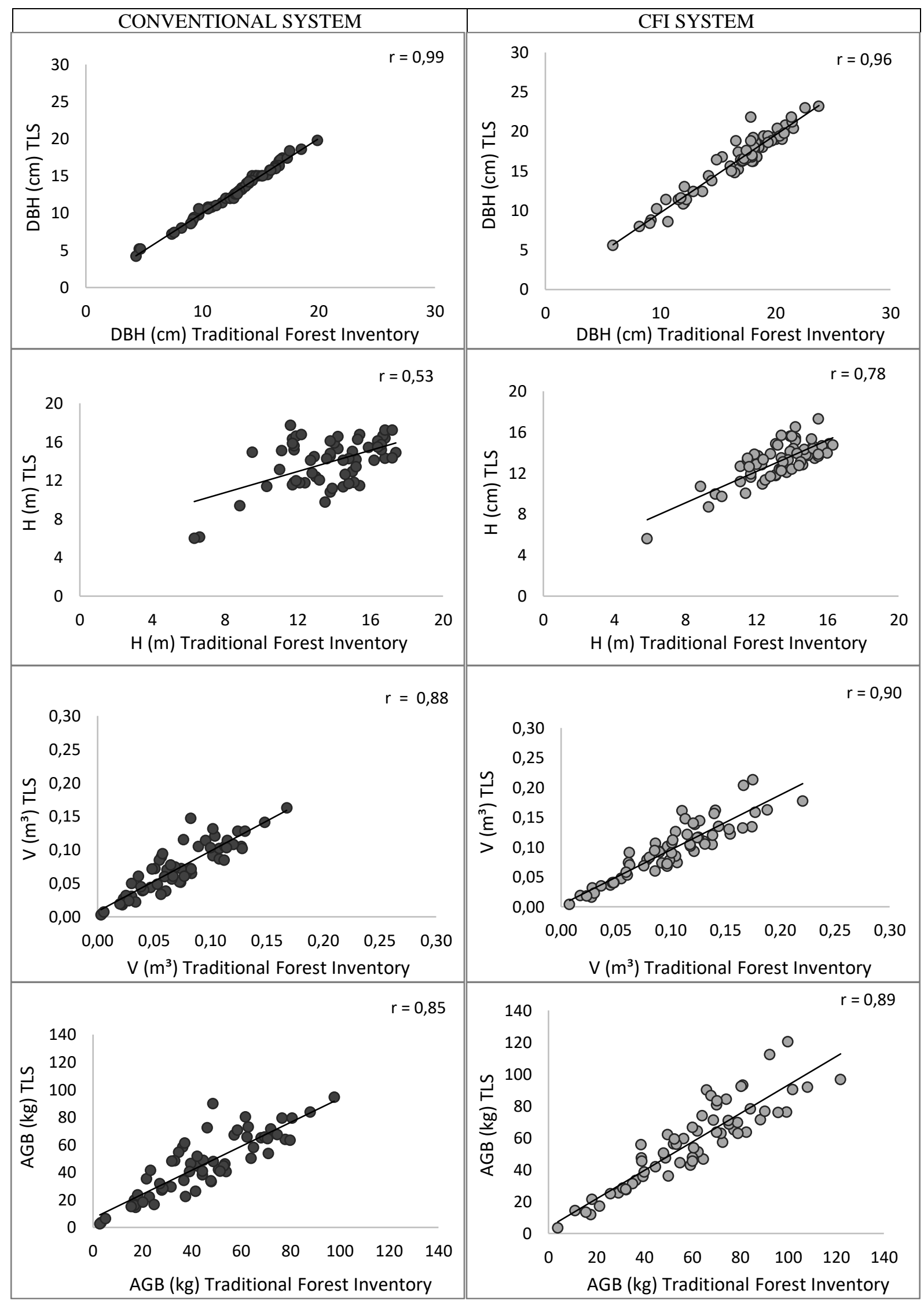

Figure 3. Relationship between the variables obtained by traditional inventory and by TLS for the conventional system and for the CFI system in Canguiri Farm - Pinhais city.

FLORESTA, Curitiba, PR, v. 51, n. 2, p. 512-520, abril/jun 2021.

Ruza, M. S. et.al.

ISSN eletrônico 1982-4688

DOI: $10.5380 /$ rf.v51 i2. 70699 
Figura 3. Relação entre as variáveis obtidas pelo inventário tradicional e pelo TLS para os sistemas de plantio convencional e iLF localizados na fazenda Canguiri - Pinhais.

\section{Development of the equation for estimating individual AGB}

In general, all the tested models presented difficulties in modeling AGB for smaller individuals, with higher dispersion at the beginning of the estimate line.

The fitting of model 5 presented the best results, with the highest adj. $\mathrm{R}^{2}$ and the lowest absolute (Syx) and relative (Syx\%) error. However, when analyzing the graphs of residues (Figure 4), model 2 showed the best distribution at the beginning of the estimate line. At that point, trees had lower DBH and H metrics and, therefore, lower AGB metrics. As the data used in this study are from individuals with only 4 years of age, indicating smaller trees compared to the individuals used in the model fitting, Equation $2(\ln \mathrm{AGB}=-3.7447+1.438 * \ln (\mathrm{DBH} * \mathrm{H})$ is the most appropriate for estimating AGB for the data in question.

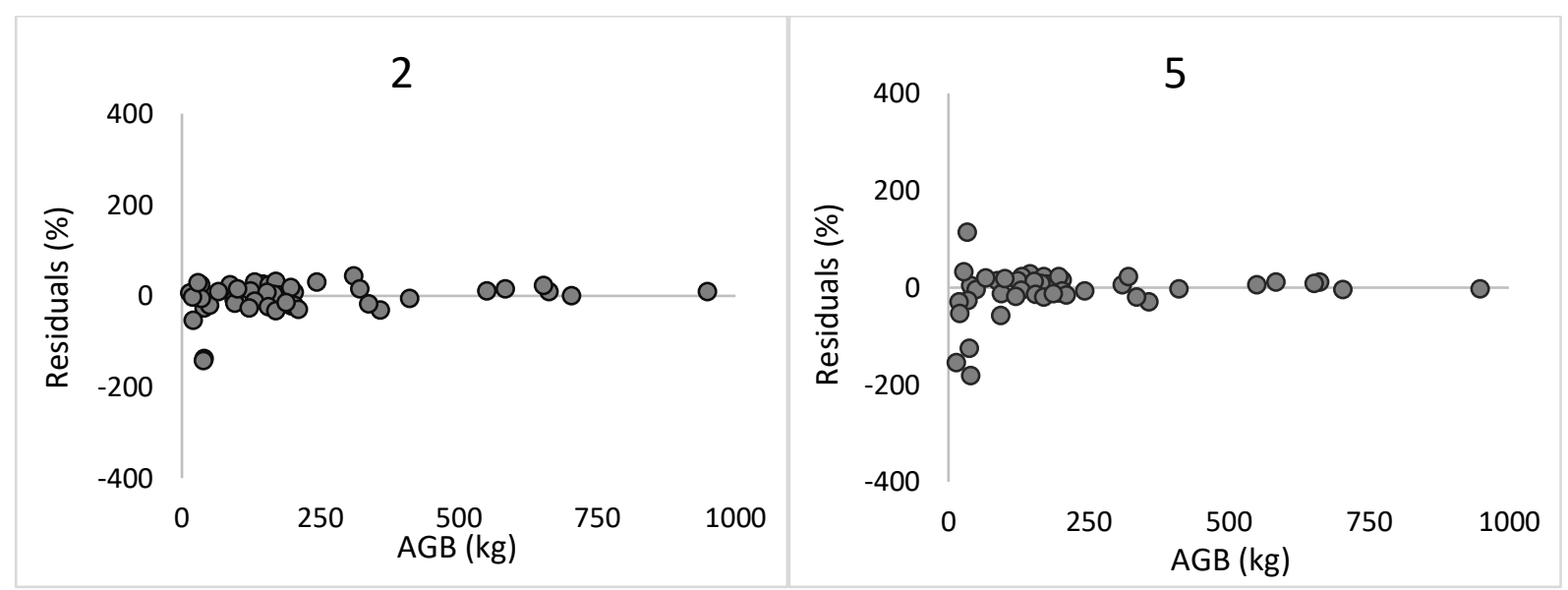

Figure 4. Distribution of residues obtained from equations used to estimate dry above-ground biomass in Eucalyptus plantations.

Figura 4. Distribuição de resíduos obtidos a partir de equações utilizadas na estimativa de biomassa seca acima do solo em plantios de Eucalyptus.

With the data of DBH, total height, estimated volume, and estimated AGB, we made an inference about the paired mean vectors. Table 2 shows the results. Both for the conventional system and for the CFI system, the Hotelling's $\mathrm{T}^{2}$ values were lower than the F values, indicating no statistical difference between the metrics obtained by traditional inventory and by TLS at $99 \%$ probability.

Table 2. Result of the inference about the paired mean vectors, measured by traditional inventory and by TLS, for the conventional system and for the CFI system.

Table 2. Result of the inference of the vectors of paired means, measured in the traditional inventory and TLS for conventional planting and for iLF.

\begin{tabular}{ccc}
\hline & F & Hotelling's T $^{\mathbf{2}}$ \\
\hline Conventional System & 15,4419 & $7,2568^{\mathrm{ns}}$ \\
CFI System & 15,3260 & $12,8319^{\mathrm{ns}}$ \\
\hline
\end{tabular}

$\mathrm{F}-\mathrm{F}$ value; $\mathrm{ns}=$ not significant at $1 \%$ probability

Table 3 presents the results obtained by the descriptive statistics for the metrics of the variables DBH, total height, volume, and AGB, obtained by traditional inventory and by TLS, for the conventional system and for the CFI system.

Table 3. Descriptive statistics for the variables DBH, total height, volume, and AGB, obtained by traditional inventory and by TLS, for the conventional system and for the CFI system in Canguiri Farm, Pinhais city.

Tabela 3. Estatística descritiva para as variáveis: dap, altura total, volume e AGB obtidos pelo inventário tradicional e pelo TLS para o sistema convencional e para o sistema iLF localizados na Fazenda Canguiri - Pinhais. 


\begin{tabular}{lcccccccc}
\hline \multicolumn{10}{c}{ Conventional System } \\
\hline & DBH $(\mathrm{cm})$ & DBH $(\mathrm{cm})$ & $\mathrm{H}(\mathrm{m})$ & $\mathrm{H}(\mathrm{m})$ & $\mathrm{V}\left(\mathrm{m}^{3}\right)$ & $\mathrm{V}\left(\mathrm{m}^{3}\right)$ & $\begin{array}{c}\text { AGB } \\
(\mathrm{kg})\end{array}$ & $\begin{array}{c}\text { AGB } \\
(\mathrm{kg})\end{array}$ \\
\hline Mean & 13,08 & 13,10 & 13,9 & 13,88 & 0,073 & 0,072 & 45,38 & 46,14 \\
Median & 13,5 & 13,40 & 14,38 & 14,31 & 0,071 & 0,071 & 44,38 & 45,86 \\
Minimum & 4,3 & 4,20 & 6,30 & 5,97 & 0,003 & 0,003 & 2,72 & 2,44 \\
Maximum & 19,9 & 19,80 & 17,40 & 17,68 & 0,168 & 0,162 & 97,76 & 94,29 \\
\hline & & & \multicolumn{7}{c}{ CFI System } & & & \\
\hline & DBH $(\mathrm{cm})$ & $\mathrm{DBH}(\mathrm{cm})$ & $\mathrm{H}(\mathrm{m})$ & $\mathrm{H}(\mathrm{m})$ & $\mathrm{V}\left(\mathrm{m}^{3}\right)$ & $\mathrm{V}\left(\mathrm{m}^{3}\right)$ & $\begin{array}{c}\text { AGB } \\
(\mathrm{kg})\end{array}$ & $\begin{array}{c}\text { AGB } \\
(\mathrm{kg})\end{array}$ \\
\hline Mean & 16,64 & 16,24 & 13,32 & 13,18 & 0,100 & 0,096 & 59,67 & 57,41 \\
Median & 17,89 & 16,80 & 13,60 & 13,44 & 0,102 & 0,094 & 60,46 & 59,50 \\
Minimum & 5,91 & 5,60 & 5,85 & 5,60 & 0,004 & 0,004 & 3,84 & 3,36 \\
Maximum & 23,80 & 23,20 & 16,30 & 17,29 & 0,223 & 0,213 & 121,94 & 120,26 \\
\hline
\end{tabular}

Traditional forest inventory

TLS

$\mathrm{DBH}$ - individual diameter at $1.30 \mathrm{~m}$ aboveground (in $\mathrm{cm}$ ); $\mathrm{H}$ - individual total height (in $\mathrm{m}$ ); $\mathrm{V}$ - individual volume with bark (in $\mathrm{m}^{3}$ ); $\mathrm{AGB}$ individual above-ground biomass (in $\mathrm{kg}$ ); $\mathrm{CV}(\%)$ - coefficient of variation (in percentage).

\section{DISCUSSION}

\section{Analysis of dendrometric variables}

Although the CFI system provides more space for the development of trees, the little difference in height growth when comparing the cropping systems proves that this variable is little influenced by initial planting density, as approached by Stage (1975). This condition can change with increasing age and competition for light; as a result, the trees grow in height, changing the result of their metrics.

When evaluating a CFI system and a conventional system for Eucalyptus cultivation, Oliveira et al. (2015) found different results. The authors observed higher total average height in the CFI system compared to the conventional system. However, they observed the variables at 13, 18, and 25 months, and the difference in total average height between systems decreased as age increased. This suggests that there may be no differences for growth in height between systems when the trees reach 4 years of age.

For height metrics in the conventional system, data dispersion was the highest among all variables. For a five-year-old Eucalyptus urograndis stand, Buck et al. (2019) used a semiautomatic method to detect the maximum height of trees. Considering the total height measured with measuring tape and that obtained by the semiautomatic detection method, the authors achieved good results in determining total height ( $\mathrm{R}^{2}$ of 0.98$)$.

Still for the variable height, the lower dispersion found in the CFI system can be justified by the ease of measuring with the clinometer in the traditional forest inventory and by the extraction of total height metrics by TLS when compared to the conventional system. The lower density of individuals enables better visualization of the base and the apex of the trees, and reduces the occurrence of measurement errors. This leads to higher correlation and lower dispersion between the collecting methods.

\section{Methods for obtaining variables}

The DBH metrics did not differ statistically between the collecting methods (traditional inventory and TLS), both for the conventional system and for the CFI system, with the difference between methods being less than $0.5 \mathrm{~cm}$. Simonse et al. (2003) used a phase-shift laser and developed an algorithm to identify individuals and to extract DBH, finding mean differences of $1.7 \mathrm{~cm}$ for DBH.

Moskal and Zheng (2012) used a procedure very similar to that used in this study to obtain diameter at breast height. The authors found an RMSE of $9.1 \mathrm{~cm}$, and attributed the results to tree occlusion, especially when dealing with larger individuals. Liang et al. (2018) divided the forest under study into three categories of complexity according to stem visibility or the level of possible effects of occlusion, and compared the result of algorithms in the extraction of DBH using simple and multiple scanning. The authors found that forests with a higher degree of complexity generally comprise trees with DBH less than $10 \mathrm{~cm}$ and greater density of plants per hectare. They concluded that when using multiple scanning data in these forests, RMSE\% can vary between 10 
and $15 \%$, and that although multiple scanning improves estimates, accurate results of DBH relate to correct stem detection. Even though the present study analyzed heterogeneous forests, the manual method used for detecting stems and extracting DBH metrics proved to be efficient.

The total height metrics obtained by traditional inventory and by TLS also did not differ significantly from each other for the two collecting methods. The values obtained by traditional inventory were slightly higher than the values obtained by TLS. This may be due to the lower point density in the covering of the apex of the trees measured with TLS.

Buck et al. (2019) studied Eucalyptus spp. individuals with ages similar to those of the individuals of this study, and applied the Filter Dmax algorithm to segment stems. The filter was not efficient below the commercial height of wood utilization $(6 \mathrm{~cm})$. The authors suggested that the influence of branches, leaves, and neighboring crowns decreased point density at the apex of the tree. Moreover, as this filter was developed for application in multiple scanning, it did not obtain good results in places with less tree cover. Martins Neto et al. (2013) also found it difficult to obtain total height metrics in trees not far from the position of the TLS equipment in the field due to the presence of branches in the canopy. Using multiple scanning, Henning and Radtke (2006) and Gatziolis et al. (2010) reported similar problems in visualizing the canopy and in obtaining total height metrics. The same problem occurred with Tian et al. (2019), who combined UAV (Unmanned Aerial Vehicle) and TLS data.

In this study, we found no difficulties in extracting total height metrics, differing from the authors mentioned above. The TLS equipment used in the field represented the trees in their entirety. This advantage can be associated with the $290^{\circ}$ vertical angular opening of the equipment and the maximum reach distance of up to $270 \mathrm{~m}$, or even with the ease of visualizing the trees, especially in the CFI system. However, it is worth considering that the trees of both systems were 4 years old in the period of data collection, and that for a population close to the age of rotation ( 7 years), the TLS used may not cover the apex of the individuals with a simple scanning.

For the CFI system, this difficulty may not be found even in advanced ages, as the spacing between individuals allows a good visualization of the entire tree, regardless of height. The greatest difficulty would probably be individualization due to crown aggregation.

\section{CONCLUSION}

- Better visualization of trees due to the higher spacing provided by the CFI system compared to the conventional system facilitated the extraction of metrics for all variables, leading to less data variability.

- The metric extraction methods (conventional inventory and terrestrial laser scanner - TLS) did not differ for the variables DBH, H, V, and AGB of four-year-old Eucalyptus trees, both for the conventional system and for the CFI system.

\section{REFERÊNCIAS}

ASSIS, P. C. R.; STONE, L. F.; MEDEIROS, J. C.; MADARIA, B. F.; OLIVEIRA, J. M.; WRUCK, F. J. Atributos físicos do solo em sistemas de integração lavoura-pecuária-floresta. Revista Brasileira de Engenharia Agrícola e Ambiental, v. 19, n. 4, p. 309-316, 2015.

ASTRUP, R.; DUCEY, M.; GRANHUS, A. Approaches for estimating stand-level volume using terrestrial laser scanning in a single-scan mode. Canadian Journal of Forest Research, v. 44, n. 6, p. 666-676. 2014.

BRASIL. Informação adicional sobre a iNDC - apenas para fins de esclarecimento. 10p. 2015.

BU, G. \& WANG, P. Adaptive circle-ellipse fitting method for estimating tree diameter based on single terrestrial laser scanning. Journal of Applied Remote Sensing, v. 10, n. 2, 2016.

BUCK, A. L. B.; LINGNAU, C.; PELliCO NETTO, S.; MACHADO, A. M. L.; MARTINS NETO, R. P. Stem modelling of Eucalyptus by terrestrial laser scanning. Floresta e Ambiente, v. 26, n. 4, p. 1-10, 2019.

DASSOT, M.; CONSTANT, T.; FOURNIER, M. The use of terrestrial LiDAR technology in forest science: application fields, benefits and challenges. Annals of forest science, v. 68, n. 5, p. 959-974, 2011.

FARDUSI, M. J., CHIANUCCI, F.; BARBATI, A. Concept to practices of geospatial information tools to assist forest management and planning under precision forestry framework: a review. Annals of Silvicultural Research, v. 41, n.1, p. 3-14, 2017.

FIGUEIREDO FILHO, A.; MACHADO, A. S.; MIRANDA, R. O. V.; RETSLAFF, F. A. Z. Compêndio de equações de volume e de afilamento de espécies florestais plantadas e nativas para as regiões geográficas do Brasil. Curitiba: os autores, 2014, 306 p. 
GATZIOLIS, D.; POPESCU, S.; SHERIDAN, R.; KU, N. Evaluation of terrestrial lidar technology for the development of local tree volume equations. Proceedings of Civilizer, p. 197-205, 2010.

HENNING, J. G.; RADTKE, P. J. Detailed stem measurements of standing trees from ground-based scanning lidar. Forest Science, v. 52, n. 1, p. 67-80, 2006.

KANKARE, V.; LIANG, X.; VASTARANTA, M.; YU, X.; HOLOPAINEN, M.; HYYPPÄ, J. Diameter distribution estimation with laser scanning based multisource single tree inventory. ISPRS Journal of Photogrammetry and Remote Sensing, v. 108, p. 161-171, 2015.

LIANG, X.; HYYPPÄ, J.; KAARTINEN. H.; LEHTOMÄKI, M. PYORALA, J.; PFEIFER, N.; HOLOPAINEN, M.; BROLLY, G.; FRANCESCO, P.; HACKENBERG, J.; HUANG, H.; JO, H.; KATOH, M.; LIU, L.; MOKRO, M.; MOREL, J.; OLOFSSON, K.; POVEDA-LOPEZ, J.; TROCHTA, J.; WANG, D.; WANG, J.; XI, Z.; YANG, B.; ZHENG, G.; KANKARE, V.; LUOMA, V.; YU, X.; CHEN, L.; VASTARANTA, M.; SAARINEN, N.; WANG, Y. International benchmarking of terrestrial laser scanning approaches for forest inventories. ISPRS Journal of Photogrammetry and Remote Sensing, v. 144, p. 137 - 179, 2018.

MARTINS NETO, R. P.; BUCK, A. L. B.; SILVA, M. N.; LINGNAU, C.; MACHADO, A. M. L.; PESCK, V. A. (2013) Avaliação da varredura laser terrestre em diferentes distâncias da árvore para mensurar variáveis dendrométricas. Boletim de Ciências Geodésicas, v. 19, n. 3, p. 420-433, 2013.

MOSKAL, M. L.; ZHENG, GUAND. Retrieving forest inventory variables with terrestrial laser scanning (TLS) in urban heterogeneous forest. Remote Sensing, v. 4, p. 1-20. 2012.

NEWNHAN, G. J.; ARMSTON, J. D.; CALDERS, K.; DISNEY, M. I.; LOVELL, J. L.; SCHAAF, C. B.; STRAHLER, A. H.; DANSON, F. M. 2015. Terrestrial Laser Scanning for Plot-Scale Forest Measurement. Current Forestry Reports, 1 (4): 239-251. Doi: 10.1007/s40725-015- 0025-5.

OLIVEIRA JUNIOR, J. C.; SOUZA, L. C. P.; MELO, V. F. Variabilidade de atributos físicos e químicos de solos da formação Guabirotuba em diferentes unidades de amostragem. Revista Brasileira de Ciência do Solo, v. 34, n. 5, p. 1491-1502, 2010.

OLIVEIRA, F. L. R.; CABACINHA, C. D.; SANTOS, L. D. T.; BARROSO, D. G.; SANTOS JUNIOR, A.; BRANT, M. C.; SAMPAIO, R. A. Crescimento inicial de eucalipto e acácia, em diferentes arranjos de integração lavoura-pecuária-floresta. Cerne, v. 21, n. 2, p. 277-233, 2015.

PASCU, I. S., DOBRE, A. C., BADEA, O., \& TANASE, M. A. (2020). Retrieval of forest structural parameters from Terrestrial Laser Scanning: A Romanian Case Study. Forests, v. 11, n. 4, p. 392, 2020.

REIS, T.; BORTOLOTTO, F.; LOPES, G. R.; BRAGA, L. (2017). Desafios e oportunidades para avançar as Contribuições Nacionais no setor agropecuário e de florestas na América Latina: $O$ caso do Brasil. Instituto de Pesquisa Ambiental da Amazônia (IPAM).

SHAO J.; ZHANG, W.; MELLADO, N.; WANG, N.; JIN, S.; CAI, S.; LUO, L.; LEJEMBLE, T.; YAN, G. SLAM-aided forest plot mapping combining terrestrial and mobile laser scanning. Jornal ISPRS de Fotogrametria e Sensoriamento Remoto , v. 163, p. 214-230, 2020.

SIMONSE, M.; ASCHOFF, T.; SPIECKER, H.; THIES, M. Automatic determination of forest inventory parameters using terrestrial laser scanning. Institute for Forest Growth, p. 1-7, 2003.

STAGE, A. R. Prediction of height increment for models of forest growth. USDA Forest Service, Ogden, 164: 120, 1975.

TIAN, J.; DAI, T.; LI, H.; LIAO, C.; TENG, W.; HU, Q.; MA, W.; XU, Y. A novel tree height extraction approach for individual trees by combining TLS and UAV image-based point cloud integration. Forests, v. 10, n. 7, p. 537, 2019. 